ISSN 1678-3921

Journal homepage: www.embrapa.br/pab

For manuscript submission and journal contents, access: www.scielo.br/pab

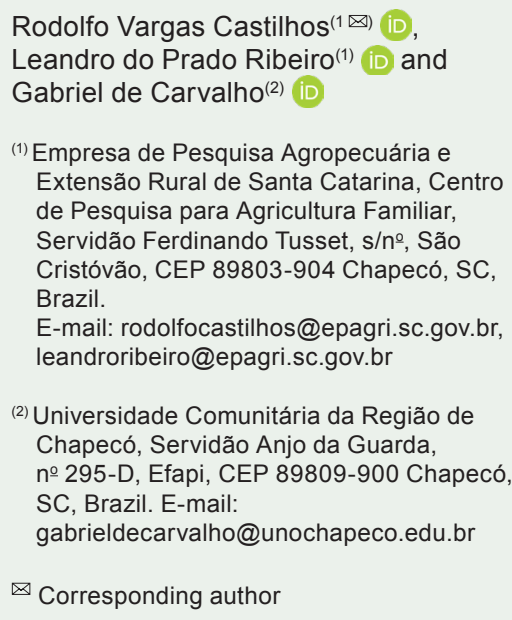

(2) Universidade Comunitária da Região de Chapecó, Servidão Anjo da Guarda, o 295-D, Efapi, CEP 89809-900 Chapecó, SC, Brazil. E-mail: gabrieldecarvalho@unochapeco.edu.br

$\bowtie$ Corresponding author

Received

July 06, 2020

Accepted

October 02, 2020

How to cite

CASTILHOS, R.V.; RIBEIRO, L. do P.; CARVALHO, G. de. Circadian feeding rhythm of green-belly stink bug in corn cultivation. Pesquisa Agropecuária Brasileira, v.56, e02123, 2021. DOI: https://doi.org/10.1590/ S1678-3921.pab2021.v56.02123.

\section{Circadian feeding rhythm of green-belly stink bug in corn cultivation}

\begin{abstract}
The objective of this work was to evaluate the circadian feeding rhythm of the green-belly stink bug (Dichelops melacanthus) on corn (Zea mays), and to correlate it with meteorological parameters. The experiments were conducted in corn fields in the first (summer) and second (fall) crop seasons, in the municipality of Chapecó, in the state of Santa Catarina, Brazil. Plants in the V3 and V5 stages were covered with cages and infested with adults of $D$. melacanthus. After 24 hours of acclimation, the number of insects feeding on the plant stem was counted every three hours (at 6:00, 9:00, 12:00, 15:00, 18:00, 21:00, and 0:00 h). At night, a red led flashlight was used to visualize the insects without interfering with their behavior. Meteorological parameters were monitored and correlated to the number of insects feeding on the plants. In the first and second crop seasons, the number of insects feeding on the corn stem differed among evaluation times, with peak in the afternoon, in the evening, and at night. Few insects were found feeding at 6:00 and 9:00 h. There was a positive correlation between air temperature and feeding in both seasons. In milder temperature regions, the preferred feeding time of $D$. melacanthus on corn is during the afternoon, evening, and night hours, which should be taken into account for a precise management of this insect.
\end{abstract}

Index terms: Dichelops melacanthus, Zea mays, feeding behavior, Pentatomidae, seedling pest.

\section{Ritmo circadiano de alimentação do percevejo barriga-verde em cultivos de milho}

Resumo - O objetivo deste trabalho foi avaliar o ritmo circadiano de alimentação do percevejo barriga-verde (Dichelops melacanthus) em milho (Zea mays), e correlacionar esse comportamento com parâmetros meteorológicos. Os experimentos foram realizados em cultivos de milho de primeira (verão) e segunda safras (outono), no município de Chapecó, no estado de Santa Catarina, Brasil. Para isso, plantas nos estágios V3 e V5 foram cobertas por gaiolas e infestadas com adultos de D. melacanthus. Após 24 horas de aclimatização, o número de insetos que se alimentava no colmo das plantas foi mensurado a cada três horas (às 6:00, 9:00, 12:00, 15:00, 18:00, 21:00 e 0:00 h). Para avaliações noturnas, utilizou-se uma lanterna com led vermelho, para visualizar os insetos sem interferir em seu comportamento. Parâmetros meteorológicos foram monitorados e correlacionados com o número de insetos que se alimentava nas plantas. Nas primeira e segunda safras, o número de insetos que se alimentava nos colmos de milho diferiu entre os horários avaliados, com maior abundância à tarde e à noite. Poucos insetos foram observados alimentando-se às 6:00 e 9:00 h. Houve correlação positiva entre a temperatura do ar e a alimentação, em ambas as safras. Em regiões de clima mais ameno, o período preferido para alimentação de $D$. 
melacanthus em milho é nas horas da tarde e da noite, o que deve ser levado em consideração para um manejo eficiente desse inseto.

Termos para indexação: Dichelops melacanthus, Zea mays, comportamento alimentar, Pentatomidae, praga inicial.

\section{Introduction}

In Brazil, the green-belly stink bug, Dichelops melacanthus (Dallas, 1851)(Hemiptera: Pentatomidae), is a serious problem in the early developmental stages of corn cultivation (Zea mays) (Bortolotto et al., 2016; Fernandes et al., 2020). Although D. melacanthus is considered a secondary soybean pest, the incidence of this species in corn cultivations has increased over the years with the massive adoption of no tillage system and second growing season of corn (Panizzi, 2015). Also, the continuous presence of cultivated and wild hosts along the year favors the survival of this insect and its occurrence on crops such as corn, on whose vegetative structures of young plants it feeds (Silva et al., 2013; Smaniotto \& Panizzi, 2015).

With the expansion of commercial Bt corn over the past 10 years and, consequently, the reduction of the use of insecticides against the fall armyworm, the incidence and damage of D. melacanthus, which was indirectly controlled depending on the insecticide sprayed, has raised in corn culture (Crosariol Netto et al., 2015). As Bt corn is ineffective against the greenbelly stink bug, this insect can reach a high population growth and cause strong economic damage in $B t$ and conventional crops, if it is not managed properly.

In cases of high infestations, management measures in corn postemergence period are necessary as a complement of seed treatment, to lessen the damage caused by $D$. melacanthus. The chemical control by spraying insecticides is the method most regularly used in the postemergence phase of corn, for the management of green-belly stink bug populations (Brustolin et al., 2011; Ávila \& Duarte, 2012; Guerreiro et al., 2017). However, failures in the chemical control in the postemergence period of the culture may occur because of the lack of knowledge on some behavioral aspects of $D$. melacanthus. When not placed in the corn stem for feeding, this species usually stays on the ground, underneath crop residue, where it can find shelter against its natural enemies and adverse conditions (Cruz et al., 2016). As many contact insecticides from the pyrethroid group, whether alone or combined with neonicotinoids, have been registered for D. melacanthus control in corn (Agrofit, 2020), the efficacy of chemical control in the postemergence period of this crop can be reduced, when most of the insects are protected in crop residue, preventing the insecticide to reach the target pest. Besides, in face of this habit, the visual observation of $D$. melacanthus on young corn crops is hindered, and the population of this insect may be underestimated during monitoring.

Most farmers and pest samplers face difficulty to visualize $D$. melacanthus in corn fields, and only detect and manage the insect when symptoms of attack are already apparent on plants. An adequate sampling and control timing are crucial for an effective management of $D$. melacanthus in the postemergence period of corn (Sosa-Gómez et al., 2020). For this, knowing the habits of this insect in corn cultivations is essential. Several studies on the bioecology of $D$. melacanthus have been carried out (Chocorosqui \& Panizzi, 2008; Bortolotto et al., 2016; Oliveira et al., 2019), and some aspects of D. melacanthus feeding on corn stems -such as body position, ingestion site, frequency, duration, and ingestion and excretion rates - were elucidated in laboratorial studies, by using the electropenetrography (EPG) technique (Lucini \& Panizzi 2017a, 2017b, 2018; Panizzi \& Lucini, 2019). In Brazil there is a prevailing "belief" that the greenbelly stink bug is more active and feeds in the early morning hours, while taking shelter under the straw layer in the warmest hours of the day; however, this "belief" cannot be entirely sustained, since there is a lack of scientific information on the circadian feeding rhythm of this species in corn fields.

A clear understanding about the preferred feeding time of D. melacanthus on corn plants along the day is essential for a precise monitoring and an effective chemical control of this pest, in the postemergence period of corn, which is optimized when insects are feeding and, consequently, more exposed to insecticide spraying.

The objective of this work was to evaluate the circadian feeding rhythm of the green-belly stink bug on corn, and to correlate it with meteorological parameters. 


\section{Materials and Methods}

The experiments were carried out in the municipality of Chapecó $\left(27^{\circ} 05^{\prime} 19^{\prime \prime} \mathrm{S}, 52^{\circ} 38^{\prime} 13^{\prime \prime} \mathrm{W}\right.$, at $658 \mathrm{~m}$ altitude), in the state of Santa Catarina, Brazil, during the 2017/2018 crop year in the first (summer) and second (fall) growing seasons.

The soil of the area is classified as Latossolo Vermelho distroférrico (Potter et al., 2004), which corresponds to Ferralsol (IUSS Working Group WRB, 2015), and it was managed under no-tillage, showing the following characteristics: $610 \mathrm{~g} \mathrm{~kg}^{-1}$ clay; $\mathrm{pH}$ water (1: 1), 5.8; $9.3 \mathrm{mg} \mathrm{dm}^{-3} \mathrm{P} ; 66.0 \mathrm{mg} \mathrm{dm}^{-3} \mathrm{~K}$; and $30 \mathrm{~g} \mathrm{~kg}^{-1}$ of organic matter (OM). The climate in this site is humid subtropical (Cfa), according to Koppen-Geiger's classification, with hot summers (Pandolfo et al, 2002).

In the first and second growing seasons, triticale (x Triticosecale Wittmack) and common bean (Phaseolus vulgaris) were the predecessor crops, respectively. Thirty days before sowing, spontaneous plants were desiccated with the use of glyphosate (Roundup Original, $480 \mathrm{~g} \mathrm{~L}^{-1}$ a.i.), and 2,4-dichlorophenoxy acetic acid (2,4-D Nortox, $806 \mathrm{~g} \mathrm{~L}^{-1}$ a.i.), at 5 and $2 \mathrm{~L} \mathrm{ha}^{-1}$, respectively. Sowing was carried out in October $5^{\text {th }}, 2017$ [first growing season (summer)] and in February $2^{\text {nd }}, 2018$ [second growing season (fall)], using the corn hybrid Pioneer 30F53 VYHR [Leptra (a transgenic event expressing the proteins CrylF, CrylAb, and VIP3Aa20 (from Bacillus thuringiensis), PAT (from Streptomyces viridochromogenes), and CP4-EPSPS (from Agrobacterium tumefaciens)]. The spacing between rows was $0.8 \mathrm{~m}$, and average sowing density was 6 seed per linear meter of row.

The basic fertilization consisted of $400 \mathrm{~kg} \mathrm{ha}^{-1}$ of $\mathrm{N}-\mathrm{P}_{2} \mathrm{O}_{5}-\mathrm{K}_{2} \mathrm{O}$ 09-33-12, according to previous analysis of the soil. In the V2 and V8 plant stages, two applications of glyphosate (Roundup Original, 480 $\mathrm{g} \mathrm{L}^{-1}$ a.i.) $+0.25 \%$ soybean oil methyl ester (Aureo, 720 $\mathrm{g} \mathrm{L}^{-1}$ a.i.) adjuvants were performed at the dosage of 3 $\mathrm{L} \mathrm{ha}^{-1}$, in a mixture volume of $150 \mathrm{~L} \mathrm{ha}^{-1}$. The application of $\mathrm{N}$ under cover was done in the V5-V6 stages, using $112.5 \mathrm{~kg} \mathrm{ha}^{-1} \mathrm{~N}$ as common urea. The other cultural treatments followed the technical recommendations for corn production in Brazil (Reunião Técnica Anual de Pesquisa de Milho, 2017), except for the application of insecticides, which was not carried out during the entire crop cycle.

In both growing seasons, 10 tulle fabric cages with $0.5 \mathrm{~m}^{2}(1 \mathrm{~m}$ length $\times 0.5 \mathrm{~m}$ width $\times 0.5 \mathrm{~m}$ height $)$ were installed, each one on five selected plants (about 1-meter row) in field plots, when plants reached the V3 and V5 stages (Ritchie et al., 1986). The straw layer in the area with cages was standardized prior to the installation of the cages.

One day before starting the evaluations (to allow of acclimation of insects in the field), each cage was infested with 5 pairs of insects (10 individuals), obtained from a laboratory colony that was maintained using the procedure described by Ribeiro et al. (2018). On each assessment day (V3 and V5 stages, in both first and second growing seasons), the infested plants were checked every 3 hours (at 6:00, 9:00, 12:00, $15: 00,18: 00,21: 00$ and $0: 00 \mathrm{~h}$ ), in order to visually verify the number of stink bugs feeding on the plant stems, following the feeding behavior described by Panizzi \& Lucini (2019). For the nocturnal evaluations, a red LED flashlight (Limatec, Cruz das Almas, BA, Brazil) was used to visualize the insects on plants without interference. Air temperature, air relative humidity, and radiation data were obtained from a meteorological station of Epagri/Cepaf, located at 50 $\mathrm{m}$ from the experimental fields.

Generalized linear models (GLM) from the exponential family of distributions (Nelder \& Wedderburn, 1972) were used to analyze the data. In all cases, the quality of fit was checked, using the half-normal probability plot with simulation envelope (Hinde \& Demétrio, 1998). When significant differences were found among the treatments, multiple comparisons (by the Tukey's post hoc test, at 5\% probability) were performed using the glht function of the multicomp package, with p-value adjustments for treatments with qualitative levels. The possible relationships between the feeding behavior and meteorological parameters were tested, using the nonparametric Spearman correlation analysis at 5\% probability. All analyses were carried out using the statistical software R, version 3.4.3 (R Core Team, 2017).

\section{Results and Discussion}

In the first crop season, the number of $D$. melacanthus feeding on corn plants in the V3 stage, in the afternoon period (12:00-18:00 h), was significantly higher than that observed at dawn $(6: 00 \mathrm{~h})$ (Figure $1 \mathrm{~A})$. The highest number $(>3.0)$ of stink bugs 
feeding on corn plants were observed at 12:00 and 15:00 $\mathrm{h}$, and differed significantly from the lowest values observed at dawn and morning. In the V5 plant stage, in the first growing season, few insects were found feeding on plant stems at 6:00 and 9:00 h; however, the feeding activity was higher from 12:00 to $0: 00 \mathrm{~h}$, with more than 4.2 insects feeding on plants (Figure $1 \mathrm{~B}$ ). For both vegetative stages, in the first growing season, the peak of insects feeding on plants occurred at 15:00 h.

For corn at the V3 stage, in the second growing season, 15:00 and 21:00 $\mathrm{h}$ were the times of the day when the highest numbers of D. melacanthus were found feeding on plant stems (3.5 and 3.6 insects, respectively), with significant difference from the values obtained from 6:00 to 12:00 h (Figure $1 \mathrm{C}$ ). At the V5 plant stage, the insect feeding activity started
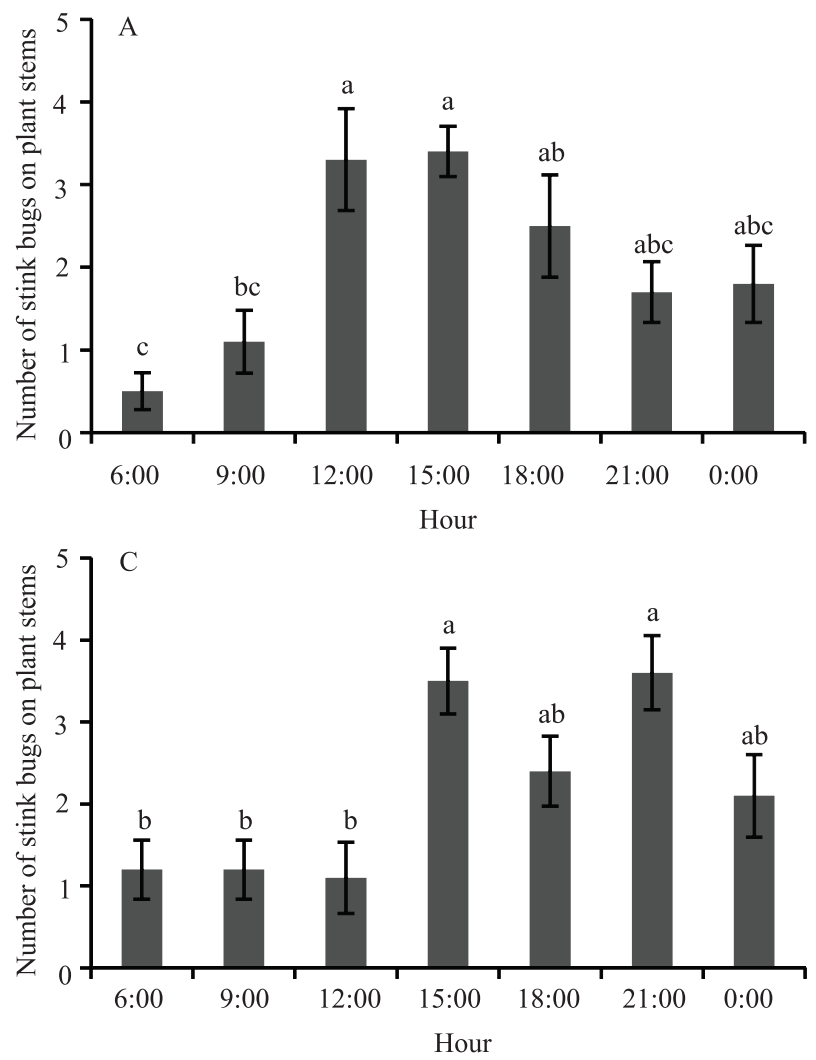

to increase at noon, with peak at 18:00 h (Figure $1 \mathrm{D}$ ). The number of stink bugs feeding on corn stem at this time was significantly higher than that observed at 6:00 and 9:00 h.

Findings from the present study show that $D$. melacanthus exhibits a circadian feeding behavior that results in different counts of stink bugs on corn stem throughout the day. In general, counts on corn plants were low at dawn and morning evaluations, and they increased at noon and afternoon with the temperature rise, evidencing that a heat uptake and raise in body temperature by solar exposure are necessary for the beginning of foraging and feeding activity (basking behavior). This behavior was reported for the first time for pentatomid bugs by Waite (1980), who verified that nymphs and adults of the phytophagous stink bug [Nezara viridula (Linnaeus, 1758) (Hemiptera:
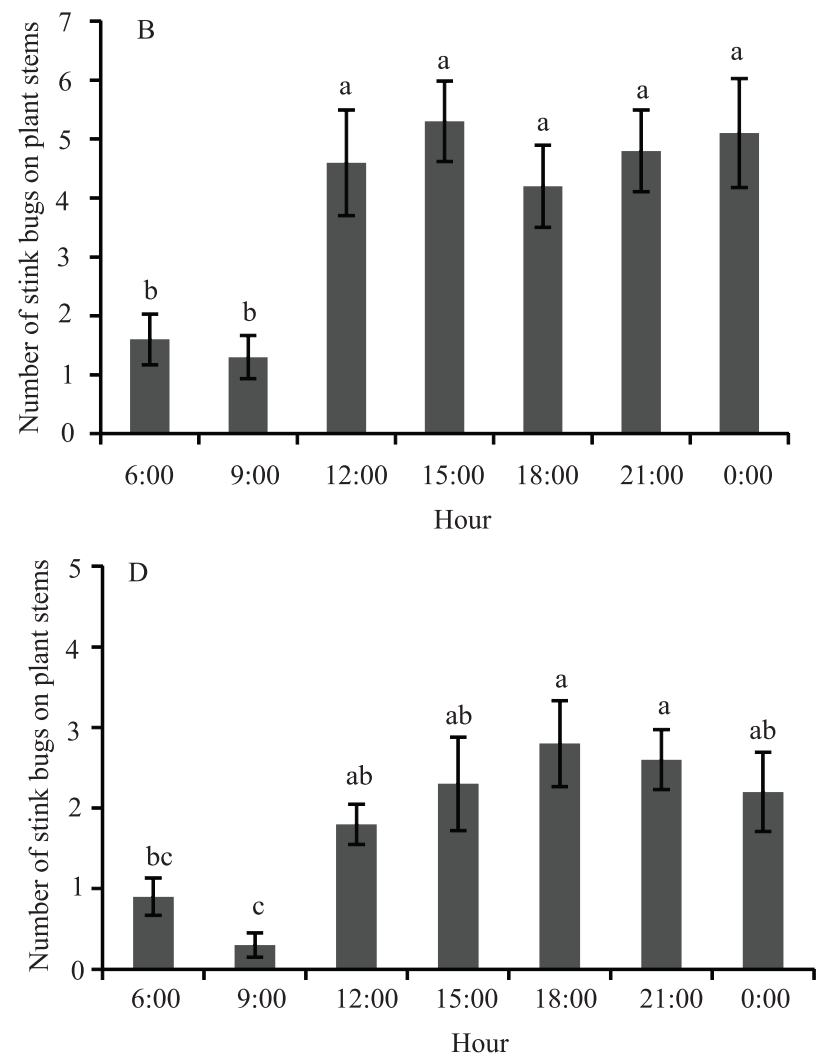

Figure 1. Number (mean $\pm \mathrm{SE}$ ) of Dichelops melacanthus feeding on corn (Zea mays) stems in the first (A, B) and second $(C, D)$ growing seasons, at different times of the day: A, first growing season, plants at the V3 stage (November $\left.1^{\text {st }}, 2017\right)$; B, first growing season, plants at the V5 stage (November $7^{\text {th }}, 2017$ ); C, second growing season, plants at the V3 stage (February $\left.16^{\text {th }}, 2018\right)$; D, second growing season, plants at the V5 stage (February $23^{\text {rd }}, 2018$ ). Means followed by different letters significantly differ (GLM with a quasi-Poisson distribution by the Tukey's post hoc test, at 5\% probability. A, $\mathrm{F}_{6,63}=$ $6.09, \mathrm{p}<0.0001 ; \mathrm{B}, \mathrm{F}_{6,63}=7.03 ; \mathrm{p}<0.0001 ; \mathrm{C}, \mathrm{F}_{6,63}=5.41 ; \mathrm{p}=0.00014 ;$ and $\mathrm{D}, \mathrm{F}_{6,63}=6.95 ; \mathrm{p}<0.0001$. 
Pentatomidae)] moved to the canopy's surface in the morning, for sunlight exposure, and remained there for a period, before reentering into the soybean plant for feeding in warmest period. Our study corroborates the findings on other species of stink bugs, such as Piezodorus guildinii (Westwood, 1837) and Bagrada hilaris (Burmeister, 1835) (both Hemiptera: Pentatomidae), which were also reported to exhibit higher feeding activity in the warmest hours of the day (Guedes et al., 2009; Huang et al., 2013).

Most insects show daily cycles of activity, and feeding usually occurs in the active period (Saunders et al., 2002; Lam \& Chiu, 2019). Because insects pose an ectothermic condition, they need an external source of heat to warm up their bodies and increment metabolism, which renders them particularly sensitive to environmental temperature (Lazzari \& Insausti, 2008).

The average air temperatures registered in the first and second growing seasons were 21.4 growing $22.7^{\circ} \mathrm{C}$, respectively, ranging from 12 to $26.2^{\circ} \mathrm{C}$ in the two days of evaluation of the first growing season, and from 15.2 to $27.4^{\circ} \mathrm{C}$ in the two days of evaluation of second growing season (Figure $2 \mathrm{~A}$ ). The average air relative humidity in the two days of evaluation, in the first growing season was $55.9 \%$, with minimum of 44.0 and maximum of $88.8 \%$, while in the second growing season, the average air relative humidity was $66 \%$, ranging from 45.4 to $90.4 \%$ (Figure 2 B). Among the meteorological parameters obtained in the evaluation days, air temperature and air relative humidity were those that most correlated with $D$. melacanthus feeding. The presence of $D$. melacanthus feeding on corn stems was positively correlated with air temperature in corn fields, in the first and second growing seasons (Table 1). Also, in the second growing season, there was a negative correlation between $D$. melacanthus feeding and air relative humidity. As stated by Jaworski \& Hilszczański (2013), temperature and humidity are the main climate parameters that can directly influence insects by limiting, or stimulating, several activities of them.

The correlation between the number of $D$. melacanthus feeding on corn stem and solar radiation was not consistent and suggests that this parameter is not a meaningful indicator of feeding activity (Table 1). Solar radiation is a relevant factor that can influence trophic interactions; however, many insects have a daily rhythm of feeding entrained mostly by temperature (Saunders et al., 2002). Although solar radiation is perceived by some insects, its effects on insect feeding are likely to be indirect, as they occur by increasing the expression of secondary metabolites and modifying the quality of plant tissues (Zavala et al., 2015).
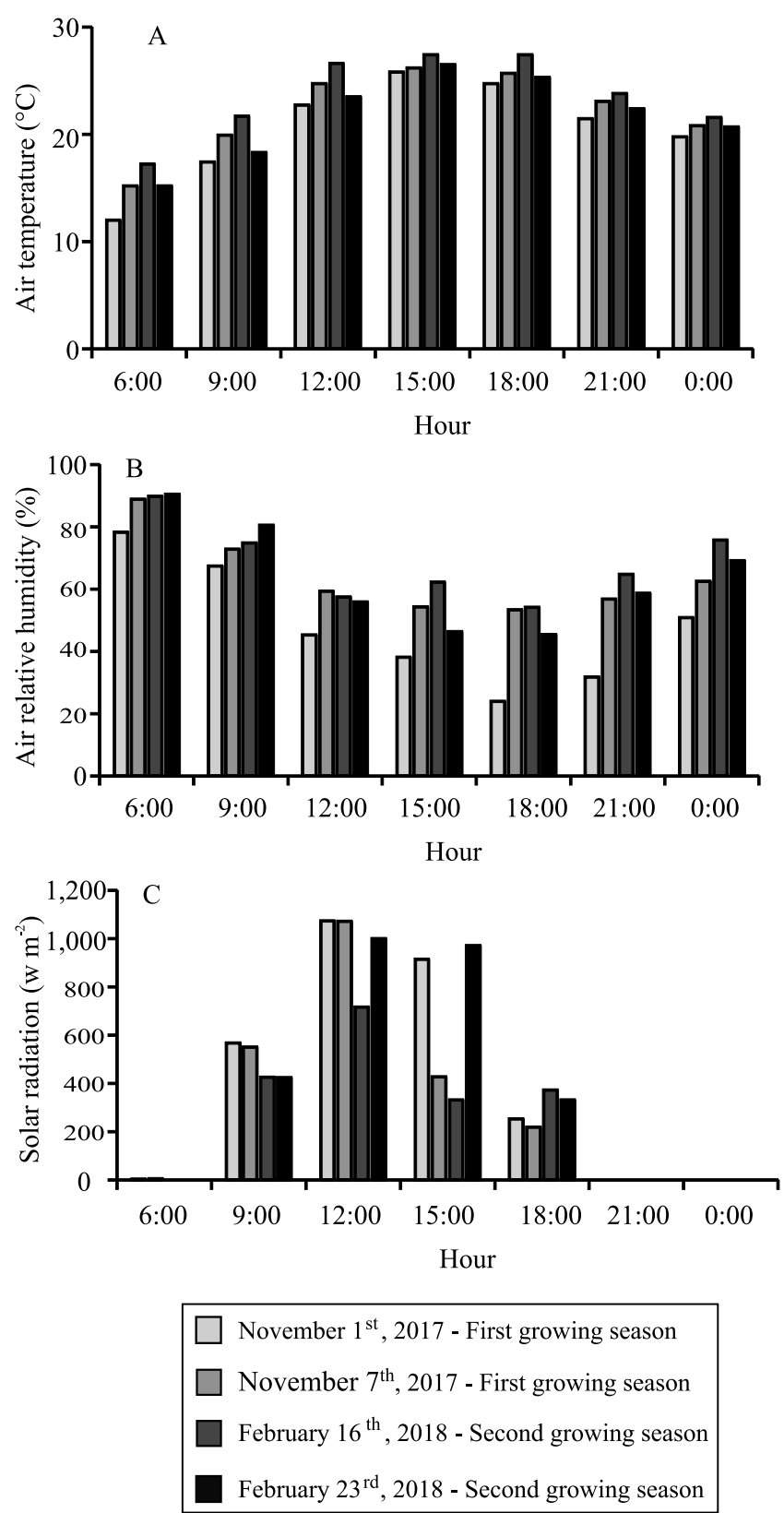

Figure 2. Meteorological parameters at the times of evaluation in the first and second growing seasons of corn (Zea mays): A, air temperature; B, air relative humidity; $\mathrm{C}$, solar radiation. 
Evaluations on both first and second growing seasons indicated that ambient temperature was the most important factor that influenced the feeding of D. melacanthus on young corn plants. Essentially, the number of stink bugs on corn stem increased according to temperature, with peak counts in the warmest period of the day, suggesting that D. melacanthus feeding is an activity triggered by temperature. The metabolism of insects is accelerated when temperatures from the surrounding environment increase to the thermal optima, directly influencing insect activities such as feeding (Jaworski \& Hilszczański, 2013). Temperatures between 25 and $31^{\circ} \mathrm{C}$ are reported to be the most favorable ones for $D$. melacanthus development, whereas mild temperatures are detrimental for the biology and activity of this species (Bortolotto et al., 2016; Oliveira et al., 2019).

Temperatures at 6:00 and 9:00 $\mathrm{h}$ ranged from 12.01 to $21.69^{\circ} \mathrm{C}$ in the evaluation days of the first and second growing seasons (Figure 2); values below the thermal optima were recorded for this species (Bortolotto et al., 2016). As stated by Lemoine et al. (2014), the herbivory of insects is directly associated with environmental temperatures, and it tends to increase with temperatures between 20 and $30^{\circ} \mathrm{C}$, as a result of the rise of metabolic demands of insects. Insects usually exert feeding in the most suitable period of the day. Feeding at temperatures below the thermal optima increases the energetic cost of movement from insects (Schowalter, 2016) which may explain the low number of green-belly stink bugs feeding from 6:00 to 9:00 h.

In our study, nighttime observations did not differ significantly from afternoon, showing that feeding by $D$. melacanthus on corn plants also occurs in nocturnal period. According to Saunders et al. (2002),

Table 1. Correlation between the observed number of Dichelops melacanthus feeding on maize plants and meteorological parameters.

\begin{tabular}{|c|c|c|}
\hline Meteorological parameter & $\mathrm{r}^{(1)}$ & p-value \\
\hline & \multicolumn{2}{|c|}{ First growing season } \\
\hline Air temperature $\left({ }^{\circ} \mathrm{C}\right)$ & 0.771 & 0.002 \\
\hline Air relative humidity $(\%)$ & -0.314 & 0.273 \\
\hline \multirow[t]{2}{*}{ Radiation $\left(\mathrm{W} \mathrm{m}^{-2}\right)$} & -0.006 & 0.982 \\
\hline & \multicolumn{2}{|c|}{ Second growing season } \\
\hline Air temperature $\left({ }^{\circ} \mathrm{C}\right)$ & 0.596 & 0.024 \\
\hline Air relative humidity $(\%)$ & -0.558 & 0.037 \\
\hline Radiation $\left(\mathrm{W} \mathrm{m}^{-2}\right)$ & -0.230 & 0.428 \\
\hline
\end{tabular}

(1)Spearman's coefficient correlation. temperature can affect the expression of the circadian photoperiodic clock in insects. As temperatures observed in nocturnal evaluations of both growing seasons were not below the thermal optima for D. melacanthus, the feeding was not inhibited at nighttime. The feeding of $D$. melacanthus in corn along the day is not a continuous, but an intermittent activity (Lucini \& Panizzi, 2017b), and our results suggest that feeding events occur both in photophase and scotophase. Therefore, spray of insecticides at night can be a viable option, since pesticides cannot be exposed to photodegradation by sunlight, which can affect the control effectiveness (Soliman, 2012).

Usually, pest samplers are recommended to monitor the green-belly stink bug at mild temperatures and to avoid the warmest hours of the day; however, this recommendation may be more suitable for warmest regions like the Brazilian savanna, where $D$. melacanthus is a serious problem in corn cultivated after soybean (Panizzi, 2015; Gomes et al., 2020). In the warmest regions of Brazil, like the Southeast, Midwest and Northeast, the diel feeding pattern of D. melacanthus might differ from that observed in our study, since increased temperatures can alter the feeding rhythm of herbivore insects (Lemoine et al., 2013). Temperatures above the optimum temperature range of a species can cause a mismatch between metabolism and consumption, leading to reductions of the ingestion efficiency and insect fitness (Lemoine \& Burkepile, 2012). Since in corn fields from Brazilian savanna the temperatures around noon and early afternoon can easily exceed the utmost optimal temperature for $D$. melacanthus $\left(30^{\circ} \mathrm{C}\right)$, the feeding of this species may occur more likely in the early hours of morning. Also, in unfavorable conditions, like extremely high temperatures and solar radiation, $D$. melacanthus find shelter under crop residue to avoid water loss (Panizzi, 2015), impairing the monitoring and chemical control when they are carried out in the afternoon.

Based on the results of the present study, the monitoring of $D$. melacanthus (visual observations on corn plants) could result in biased low estimates of population in the South of Brazil, where temperatures are relatively milder, if carried out during the coolest hours of morning (6:00 to 9:00), in the first and second corn growing seasons. The economic threshold level of D. melacanthus on corn is three 
adults per meter of row (Gomes et al., 2020), and an inaccurate monitoring may lead to significant plant damage or unnecessary insecticide spray. Hence, the monitoring and the attainment of reliable results of D. melacanthus densities are essential for precise control decisions. Because corn growers usually rely on contact insecticides for managing $D$. melacanthus outbreaks, for their postemergence application to corn, sprays carried out in the afternoon, evening, and even at night, when insects are more active and feeding on corn stem, are probably more effective than during morning hours.

\section{Conclusions}

1. The green-bellystinkbug(Dichelops melacanthus) exhibits a circadian feeding rhythm on corn (Zea mays) plants, with few insects feeding early in the morning and with a more pronounced feeding activity in the afternoon, evening and night hours.

2. Air temperature is the main meteorological parameter that influences the feeding activity of $D$. melacanthus on corn crop.

\section{Acknowledgments}

To the field technician Luiz Dalcin, from Empresa de Pesquisa Agropecuária e Extensão Rural de Santa Catarina, Centro de Pesquisa para Agricultura Familiar (Epagri/Cepaf) and his team, for the assistance in corn cultivation conduction; to the laboratory technicians Carmen dos Santos, Michelle Silva, Neusa Maciel, and Zelinda Meneguzzi (all from Epagri/Cepaf), for insect rearing, and to Dr. Cristiano Nunes Nesi (Epagri/ Cepaf) for statistical assistance.

\section{References}

AGROFIT: Sistema de Agrotóxicos Fitossanitários. Available at: $<$ http://agrofit.agricultura.gov.br/agrofit_cons/principal_agrofit_ cons>. Accessed on: Apr. 242020.

ÁVILA, C.J.; DUARTE, M.M. Eficiência de inseticidas, aplicados nas sementes e em pulverização, no controle do percevejo barrigaverde Dichelops melacanthus (Dallas) (Hemiptera: Pentatomidae), na cultura do milho. BioAssay, v.7, p.1-6, 2012. DOI: https://doi.org/10.14295/BA.v7.0.72.

BORTOLOTTO, O.C.; MIKAMI, A.Y.; BUENO, A. de F.; SILVA, G.V.; QUEIROZ, A.P. de. Aspectos biológicos de Dichelops melacanthus em três temperaturas, alimentados com grãos imaturos de milho 2B688Hx e 2B688. Ciência Rural, v.46, p.254259, 2016. DOI: https://doi.org/10.1590/0103-8478cr20150542.
BRUSTOLIN, C.; BIANCO, R.; NEVES, P.M.O.J. Inseticidas em pré e pós-emergência do milho (Zea mays L.), associados ao tratamento de sementes, sobre Dichelops melacanthus (Dallas) (Hemiptera: Pentatomidae). Revista Brasileira de Milho e Sorgo, v.10, p.215-223, 2011. DOI: https://doi.org/10.18512/19806477/ rbms.v10n3p215-223.

CHOCOROSQUI, V.R.; PANIZZI, A.R. Nymph and adult biology of Dichelops melacanthus (Dallas) (Heteroptera: Pentatomidae) feeding on cultivated and non-cultivated host plants. Neotropical Entomology, v.37, p.353-360, 2008. DOI: https://doi.org/10.1590/ S1519-566X2008000400001.

CROSARIOL NETTO, J.; MICHELOTTO, M.D.; GRIGOLLI, J.F.J.; GALLI, J.A.; PIROTTA, M.Z.; BUSOLI, A.C. Damages caused by Dichelops melacanthus (Heteroptera: Pentatomidae) in conventional and transgenic corn hybrids. Bioscience Journal, v.31, p.1092-1101, 2015. DOI: https://doi.org/10.14393/BJv31n4a2015-26323.

CRUZ, I.; BIANCO, R.; REDOAN, A.C.M. Potential risk of losses in maize caused by Dichelops melacanthus (Dallas) (Hemiptera: Pentatomidae) in Brazil. Revista Brasileira de Milho e Sorgo, v.15, p.386-397, 2016. DOI: https://doi.org/10.18512/1980-6477/ rbms.v15n3p386-397.

FERNANDES, P.H.R.; ÁVILA, C.J.; SILVA, I.F. da; ZULIN, D. Damage by the green-belly stink bug to corn. Pesquisa Agropecuária Brasileira, v.55, e01131, 2020. DOI: https://doi.org/10.1590/S1678-3921.pab2020.v55.01131.

GOMES, E.C.; HAYASHIDA, R.; BUENO, A. de F. Dichelops melacanthus and Euschistus heros injury on maize: basis for re-evaluating stink bug thresholds for IPM decisions. Crop Protection, v.130, art.105050, 2020. DOI: https://doi.org/10.1016/j. cropro.2019.105050.

GUEDES, J.V.C.; KUSS ROGGIA, R.C.R.; STURMER, G.R.; ARNEMANN, J.A. Percevejos da soja: proporção de espécies e distribuição espaço-temporal. Revista Plantio Direto, v.108, p.15-21, 2009.

GUERREIRO, J.C.; SILVA, G.B.; AZEVEDO, A.P.; SPESSATO, R.R.; PADOVAN, A.T.; LEITE, F.; FERREIRA FILHO, P.J. Controle de Dichelops melacanthus com inseticidas aplicados em épocas diferentes associados a enxofre no milho. Scientific Electronic Archives, v.10, p.67-74, 2017. DOI: https://doi.org/10.36560/1012017360.

HINDE, J.; DEMÉTRIO, C.G.B. Overdispersion: models and estimation. Computational Statistics and Data Analysis, v.27, p.151-170, 1998. DOI: https://doi.org/10.1016/S01679473(98)00007-3.

HUANG, T.; REED, D.A.; PERRING, T.M.; PALUMBO, J.C. Diel activity and behavior of Bagrada hilaris (Hemiptera: Pentatomidae) on desert cole crops. Journal of Economic Entomology, v.106, p.1726-1738, 2013. DOI: https://doi.org/10.1603/EC13048.

IUSS WORKING GROUP WRB. World Reference Base for Soil Resources 2014: international soil classification system for naming soils and creating legends for soil maps: update 2015. Rome: FAO, 2015. (FAO. World Soil Resources Reports, 106). Available at: <http://www.fao.org/3/i3794en/I3794en.pdf >. Accessed on: June 2020. 
JAWORSKI, T.; HILSZCZAŃSKI, J. The effect of temperature and humidity changes on insects development and their impact on forest ecosystems in the context of expected climate changes. Forest Research Papers, v.74, p.345-355, 2013. DOI: https://doi.org/10.2478/frp-2013-0033.

LAM, V.H.; CHIU, J.C. Evolution and design of invertebrate circadian clocks. In: BYRNE, J.H. (Ed.). The Oxford handbook of invertebrate neurobiology. Oxford: Oxford University Press, 2019. DOI: https://oi.org/10.1093/ oxfordhb/9780190456757.013.25.

LAZZARI, C.R.; INSAUSTI, T.C. Circadian rhythms in insects. In: FANJUL-MOLES, M.L.; ROBLERO, R.A (Ed.). Comparative aspects of circadian rhythms. Kerala: Transworld Research Network, 2008. p.1-18.

LEMOINE, N.P.; BURKEPILE, D.E. Temperature-induced mismatches between consumption and metabolism reduce consumer fitness. Ecology, v.93, p.2483-2489, 2012. DOI: https://doi.org/10.1890/12-0375.1.

LEMOINE, N.P.; BURKEPILE, D.E.; PARKER, J.D. Variable effects of temperature on insect herbivory. Peer Journal, v.2, e376, 2014. DOI: https://doi.org/10.7717/peerj.376.

LEMOINE, N.P.; DREWS, W.A.; BURKEPILE, D.E.; PARKER, J.D. Increased temperature alters feeding behavior of a generalist herbivore. Oikos, v.122, p.1669-1678, 2013. DOI: https://doi.org/10.1111/j.1600-0706.2013.00457.x.

LUCINI, T.; PANIZZI, A.R. Behavioral comparisons of ingestion and excretion by selected species of pentatomids: evidence of feeding on different food sources supports pest status. Neotropical Entomology, v.46, p.361-367, 2017b. DOI: https://doi.org/10.1007/ s13744-016-0474-y.

LUCINI, T.; PANIZZI, A.R. Electropenetrography (EPG): a breakthrough tool unveiling stink bug (Pentatomidae) feeding on plants. Neotropical Entomology, v.47, p.6-18, 2018. DOI: https://doi.org/10.1007/s13744-017-0574-3.

LUCINI, T.; PANIZZI, A.R. Feeding behavior of the stink bug Dichelops melacanthus (Heteroptera: Pentatomidae) on maize seedlings: an EPG analysis at multiple input impedances and histology correlation. Annals of the Entomological Society of America, v.110, p.160-171, 2017a. DOI: https://doi.org/10.1093/ aesa/saw070.

NELDER, J.A.; WEDDERBURN, R.W.M. Generalized linear models. Journal of the Royal Statistical Society Series A-General, v.135, p.370-384, 1972.

OLIVEIRA, L.M. de; HOSHINO, A.T.; MENEZES JR., A. de O.; CAVIGLIONE, J.H.; BIANCO, R.; ANDROCIOLI, H.G. Greenbelly stinkbug biology in different temperatures. Journal of Agricultural Science, v.11, p.267-271, 2019. DOI: https://doi.org/10.5539/jas.v11n18p267.

PANDOLFO, C.M.; BRAGA, H.J.; SILVA JÚNIOR, V.P.; MASSIGNAM, A.M.; PEREIRA, E.S.; THOMÉ, V.M.R.; VALCI, F.V. Atlas climatológico do estado de Santa Catarina. Florianópolis: Epagri, 2002.

PANIZZI, A.R. Growing problems with stink bugs (Hemiptera: Heteroptera: Pentatomidae): species invasive to the U.S. and potential Neotropical invaders. American Entomologist, v.61, p.223-233, 2015. DOI: https://doi.org/10.1093/ae/tmv068.
PANIZZI, A.R.; LUCINI, T. Body position of the stink bug Dichelops melacanthus (Dallas) during feeding from stems of maize seedlings. Brazilian Journal of Biology, v.79, p.304-310, 2019. DOI: https://doi.org/10.1590/1519-6984.18250.

POTTER, R.O.; CARVAlHO, A.P. de; FlORES, C. A.; BOGNOLA, I. Solos do Estado de Santa Catarina. Rio de Janeiro: Embrapa Solos, 2004. 713p. (Embrapa Solos. Boletim de pesquisa e desenvolvimento, 46).

R CORE TEAM. R: A language and environment for statistical computing. Vienna: R Foundation for Statistical Computing, 2017.

REUNIÃO TÉCNICA ANUAL DE PESQUISA DE MILHO, 62.; REUNIÃO TÉCNICA ANUAL DE PESQUISA DE SORGO, 45., 2017, Sertão. Indicações técnicas para o cultivo de milho e de sorgo no Rio Grande do Sul: safras 2017/2018 e 2018/2019. Brasília: Embrapa, 2017. Editores técnicos Ana Paula Schneid Afonso da Rosa, Beatriz Marti Emygdio e Noryam Bervian Bispo.

RIBEIRO, L. do P.; KLOCK, A.L.S.; WORDELL FILHO, J.A.; TRAMONTIN, M.A.; TRAPP, M.A.; MITHÖFER, A.; NANSEN, C. Hyperspectral imaging to characterize plant-plant communication in response to insect herbivory. Plant Methods, v.14, art.54, 2018. DOI: https://doi.org/10.1186/s13007-018-0322-7.

RITCHIE, S.W.; HANWAY, J.J.; BENSON, G.O. How a corn plant develops. Ames: Iowa State University of Science and Technology, 1986. 21p. (Special Report, 48).

SAUNDERS, D.S; STEEL, C.G.H.; VAFOPOULOU, X.; LEWIS, R.D. Insect clocks. $3^{\text {rd }}$ ed. Amsterdan: Elsevier, 2002. 576p. DOI: https://doi.org/10.1016/B978-0-444-50407-4.X5000-9.

SCHOWALTER, T.D. Insect ecology: an ecosystem approach. $4^{\text {th }}$ ed. Amsterdan: Elsevier, 2016. 774p. DOI: https://oi.org/10.1016/ C2014-0-04067-1.

SILVA, J.J.; VENTURA, M.U.; SILVA, F.A.C.; PANIZZI, A.R. Population dynamics of Dichelops melacanthus (Dallas) (Heteroptera: Pentatomidae) on host plants. Neotropical Entomology, v.42, p.141-145, 2013. DOI: https://doi.org/10.1007/ s13744-012-0104-2.

SMANIOTTO, L.F.; PANIZZI, A.R. Interactions of selected species of stink bugs (Hemiptera: Heteroptera: Pentatomidae) from leguminous crops with plants in the Neotropics. Florida Entomologist, v.98, p.7-17, 2015. DOI: https://doi.org/10.1653/024.098.0103.

SOLIMAN, M.M.M. Effects of UV-light, temperature and storage on the stability and biological effectiveness of some insecticides. Journal of Plant Protection Research, v.52, p.275-280, 2012. DOI: https://doi.org/10.2478/v10045-012-0044-1.

SOSA-GÓMEZ, D.R.; CORRÊA-FERREIRA, B.S.; KRAEMER, B.; PASINI, A.; HUSCH, P.E.; VIEIRA, C.E.D.; MARTINEZ, C.B.R.; LOPES, I.O.N. Prevalence, damage, management and insecticide resistance of stink bug populations (Hemiptera: Pentatomidae) in commodity crops. Agricultural and Forest Entomology, v.22, p.99-118, 2020. DOI: https://doi.org/10.1111/ afe. 12366 .

WAITE, G.K. The basking behavior of Nezara viridula (L.) (Pentatomidae: Hemiptera) on soybeans and its implication in control. Australian Journal of Entomology, v.19, p.157-159, 1980. DOI: https://doi.org/10.1111/j.1440-6055.1980.tb00978.x. 
ZAVALA, J.A.; MAZZA, C.A.; DILLON, F.M.; CHLUDIL, H.D.; BALLARÉ, C.L. Soybean resistance to stink bugs (Nezara viridula and Piezodorus guildinii) increases with exposure to solar UV-B radiation and correlates with isoflavonoid content in pods under field conditions. Plant, Cell and Environment, v.38, p.920-928, 2015. DOI: https://doi.org/10.1111/pce.12368. 